\title{
Influence of goat's-milk folate-binding protein on transport of 5-methyltetrahydrofolate in neonatal-goat small intestinal brush-border-membrane vesicles
}

\author{
BY DALLYN N. SALTER \\ Department of Pig Nutrition and Production, AFRC Institute for Grassland and Animal \\ Production, Shinfield, Reading RG2 $9 A Q$ \\ AND PETER BLAKEBOROUGH \\ Department of Food Quality and Human Nutrition, AFRC Institute of Food Research, \\ Reading Laboratory, Shinfield, Reading RG2 $9 A T$
}

\section{(Received 1 December 1987 - Accepted 15 January 1988)}

1. The influence of goat's-milk folate-binding protein (FBP) on the uptake of 5-methyltetrahydrofolate (MTHF) by brush-border-membrane vesicles prepared from the small intestine of the 6-d-old goat was investigated using a rapid-filtration assay.

2. Uptake of MTHF by the membrane vesicles was strongly enhanced by FBP within the pH range $4 \cdot 5-6 \cdot 5$, with an optimum at $\mathrm{pH} 5-5 \cdot 5$.

3. Both the initial rate of MTHF uptake and uptake of MTHF at equilibrium were markedly increased in the presence of FBP.

4. Uptake of MTHF by brush-border-membrane vesicles was maximal when the molar ratio FBP:MTHF was $1 \cdot 0-2 \cdot 5$.

5. The relation between $\mathrm{pH}$ and ${ }^{125} \mathrm{I}$-labelled FBP binding to the membranes was similar to that for uptake of MTHF, with an optimum at $\mathrm{pH} 5$.

6. In experiments in which the osmotic pressure of the incubation medium was progressively increased with cellobiose, ${ }^{125}$ I-labelled FBP was found to be taken up primarily by binding to the brush-border-membrane surface.

7. Uptake of ${ }^{125} \mathrm{I}$-labelled FBP was time-dependent and saturable, with a $K_{m}$ of 0.39 (SE 0.07) $\mu \mathrm{M}$ and $V_{\max }$ of 6.73 (SE 0.92) $\mu \mathrm{g} / \mathrm{mg}$ protein.

8. Experiments in which various milk proteins (cow FBP, goat FBP, $\alpha$-lactalbumin, $\beta$-lactoglobulin, bovine serum albumin and lactoferrin) were allowed to compete in turn with ${ }^{125}$ I-labelled FBP for uptake by brushborder-membrane vesicles indicated that high-affinity binding was probably specific to FBP, although lactoferrin reduced uptake possibly by non-specific coating of the mucosal surface.

9. It was concluded that a folate transport mechanism mediated by the FBP in milk exists at the intestinal brush border of neonatal goats. It is suggested that this may reinforce the developing endogenous transport system.

Folate-binding proteins (FBP) are a group of immunologically cross-reactive membranebound and soluble proteins, which bind folates with high affinity (dissociation constant, $K_{d}$ approximately $10^{-9}-10^{-10} \mathrm{M}$ ) and are found in many tissues and body fluids (Kane et al. 1986). The soluble FBP of cow's milk has been isolated as a glycoprotein of subunit molecular weight 35000 which binds $1 \mathrm{~mol}$ folate/mol protein at $\mathrm{pH} \mathrm{7.2}$ (Salter et al. 1981).

The possible physiological functions of the milk FBP remain controversial. In the gut of the milk-fed animal FBP may compete with bacteria in sequestering folate in a form that is available for uptake at the mucosal surface (Ford, 1974). It may also serve in facilitating folate uptake by interacting with mucosal receptors, but there has hitherto been little direct evidence for this. Folic acid uptake by rat intestinal cells in vitro increased twofold when the vitamin was in a bound form in skimmed milk, compared with free folic acid, although FBP was not shown specifically to enhance uptake (Colman et al. 1981). However, in human nasopharyngeal epidermoid carcinoma (KB) cells an FBP has been implicated in folate transport (Antony et al. 1983). 
The present work was undertaken to determine whether added goat's-milk FBP could increase intestinal folate transport using the in vitro system of brush-border-membrane vesicles from infant goats, previously used to characterize folate transport (Blakeborough \& Salter, 1988). The goat was used because its milk provides a relatively rich source of binder for the preparation of useful amounts of the purified FBP, and the protein is very similar in structure to both human- and cow's-milk FBP (Svendsen et al. 1982). Preliminary accounts of some of the results presented here have been reported previously (Blakeborough \& Salter, 1985; Trugo \& Salter, 1986).

\section{MATERIALS AND METHODS}

\section{Materials}

Bovine serum albumin (BSA; fraction V), Hepes, Mes (2[N-morpholino] ethanesulphonic acid), $\alpha$-lactalbumin (Type 1) and $\beta$-lactoglobulin from cow's milk, and 5-methyltetrahydrofolate (barium salt; MTHF) were obtained from Sigma Chemical Co. Ltd, Poole, Dorset. Bolton and Hunter reagent (containing $1 \mathrm{mCi}^{125} \mathrm{I}$ ) and $\left[{ }^{14} \mathrm{C}\right] \mathrm{MTHF}$ $(58 \mathrm{mCi} / \mathrm{mmol})$ were obtained from Amersham International plc, Amersham, Bucks. Other chemicals were purchased from BDH Chemical Co. Ltd, Poole, and were of analytical grade where possible.

\section{Preparative techniques}

Brush-border-membrane vesicles were prepared from the whole small intestine of a 6-d-old suckled goat which had been fasted overnight, as described previously (Blakeborough \& Salter, 1988).

FBP ( $>95 \%$ pure) was prepared from cow's and goat's milk and its purity checked by the procedures of Salter et al. (1981). The purified goat's milk FBP $(5 \mu \mathrm{g})$ was labelled with ${ }^{125} \mathrm{I}(1 \mathrm{mCi})$ by the method of Bolton \& Hunter (1973). Excess ${ }^{125} \mathrm{I}$ was removed by chromatography on Sephadex G75. The specific radioactivity of different preparations of ${ }^{125} \mathrm{I}$-labelled FBP ranged from 10 to $50 \mu \mathrm{Ci} / \mu \mathrm{g}$. Radioactivity (counts/min) per sample for $0.0001 \mu \mathrm{mol}{ }^{125}$ I-labelled FBP varied from 6.3 to $31.5 \times 10^{6}$. The proportion of proteinbound ${ }^{125} \mathrm{I}$ was checked at regular intervals by 'instant' thin-layer chromatography (Gelman Sciences Inc., Ann Arbor, MI, USA) and found to remain above $95 \%$ during the course of storage at $-20^{\circ}$ for up to 2 months. The ${ }^{125} \mathrm{I}$-labelled FBP was diluted with unlabelled FBP from the same preparations to achieve the desired concentrations.

Lactoferrin was purified from human milk as described by Blakeborough et al. (1983).

\section{Analytical techniques}

Protein was assayed as described by Bensadoun \& Weinstein (1976). ${ }^{14} \mathrm{C}$ was estimated by liquid-scintillation techniques after the addition of $10 \mathrm{ml}$ Instagel (Packard Instrument Co. Inc., Illinois, USA) to the samples. ${ }^{125} \mathrm{I}$ was estimated using an Intertech CG 4000 $\gamma$-scintillation spectrometer.

\section{Experimental}

The experimental protocol for studying the uptake of folates by brush-border-membrane vesicles has been described previously (Blakeborough \& Salter, 1988). The experimental conditions were as follows. (1) To determine the effect of FBP and $\mathrm{pH}$ on the uptake of folates, the vesicles ( $50 \mu \mathrm{g}$ protein) were incubated for $15 \mathrm{~min}$ with $\left[{ }^{14} \mathrm{C}\right] \mathrm{MTHF}(2 \mu \mathrm{M})$ and FBP (0 or $2 \mu \mathrm{M})$ at $\mathrm{pH} 4-8$. (2) In experiments to determine the influence of FBP on the time-course of folate uptake, vesicles were incubated with $\left[{ }^{14} \mathrm{C}\right] \mathrm{MTHF}(0.5 \mu \mathrm{M})$ and FBP 


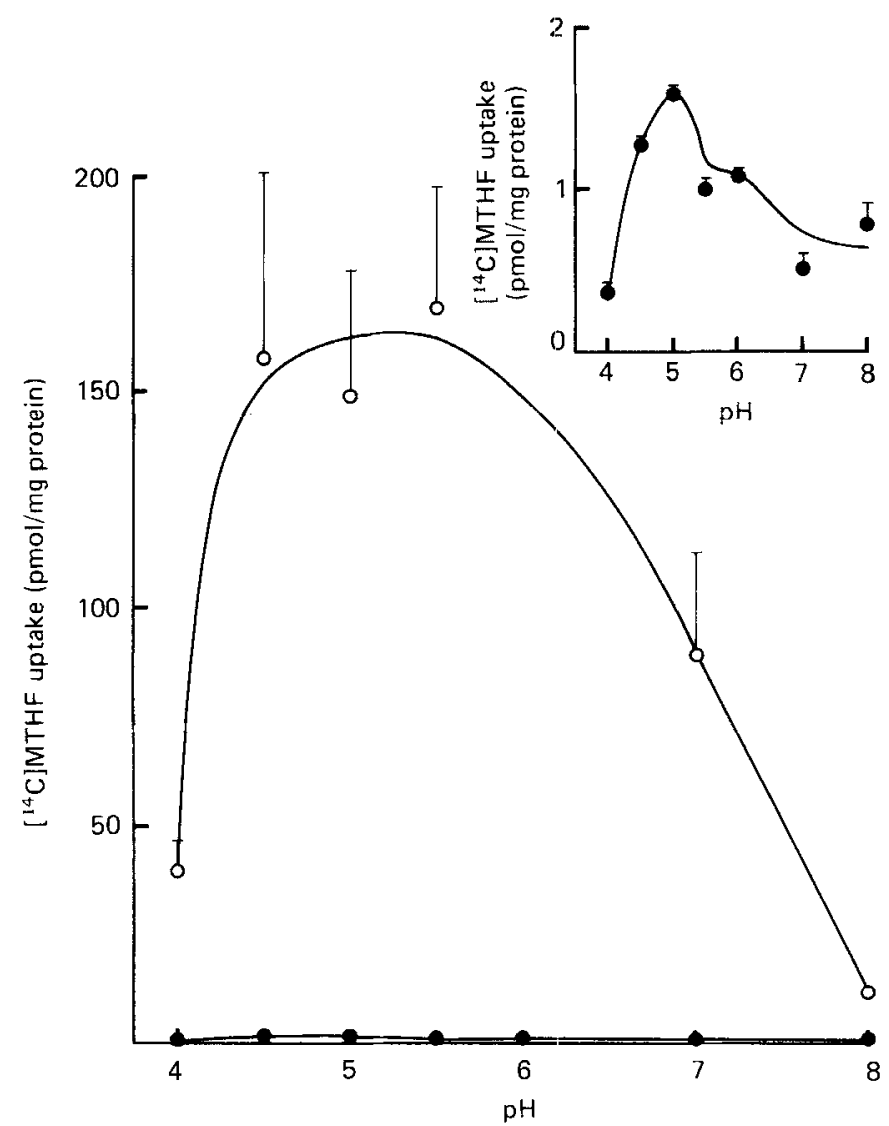

Fig. 1. The effect of $\mathrm{pH}$ on the uptake of free $5-\left[{ }^{14} \mathrm{C}\right]$ methyltetrahydrofolate (MTHF) and $\left[{ }^{14} \mathrm{C}\right] \mathrm{MTHF}$ complexed to folate-binding protein (FBP) by brush-border-membrane vesicles. Membrane vesicles $\left(50 \mu \mathrm{g}\right.$ protein) were incubated with $\left[{ }^{14} \mathrm{C}\right] \mathrm{MTHF}(2 \mu \mathrm{M})$ in the absence $(O)$ and presence $(\mathrm{O})$ of FBP $(2 \mu \mathrm{M})$, for $15 \mathrm{~min}$ at $25^{\circ}, \mathrm{pH} 48$. Results are the means of three determinations, with their standard errors represented by vertical bars. Where no bars are shown the standard errors fall within the experimental points as drawn. The inset shows a magnification of the lower curve (uptake of $\left[{ }^{14} \mathrm{C}\right] \mathrm{MTHF}$ in the absence of FBP).

(0 and $0.5 \mu \mathrm{M}$ ) for $1-30 \mathrm{~min}$ at $\mathrm{pH} 5 \cdot 0$. (3) To determine the optimum molar ratio, FBP: folate for uptake, vesicles were incubated with $\left[{ }^{14} \mathrm{C}\right] \mathrm{MTHF}(0.5-2 \mu \mathrm{M})$ and FBP in a molar ratio FBP: MTHF of $0-5$ for $30 \mathrm{~min}$ at $\mathrm{pH} 5 \cdot 0$.

In experiments to study the uptake of ${ }^{125}$ I-labelled FBP by brush-border-membrane vesicles, the protocol was the same as that described previously for MTHF. (1) To determine the effect of $\mathrm{pH}$ on FBP uptake, vesicles were incubated with ${ }^{125}$ I-labelled FBP $(20 \mu \mathrm{g} / \mathrm{ml})$ for $15 \mathrm{~min}$ at $\mathrm{pH} 4-8$. (2) The time-course of FBP uptake was studied by incubating vesicles with ${ }^{125} \mathrm{I}$-labelled FBP $(1-40 \mu \mathrm{g} / \mathrm{ml})$ for $1-30 \mathrm{~min}$ at $\mathrm{pH} 5 \cdot 0$. (3) To distinguish between transport and membrane binding, vesicles were incubated with various concentrations of cellobiose $(10,25$ and $50 \mathrm{~g} / \mathrm{l})$, together with ${ }^{125} \mathrm{I}$-labelled FBP $(1 \mu \mathrm{g} / \mathrm{ml})$ for $1 \mathrm{~min}$ at $\mathrm{pH} 5 \cdot 0$. (4) The specificity of uptake of ${ }^{125} \mathrm{I}$-labelled FBP $(20 \mu \mathrm{g} / \mathrm{ml})$ was determined in the presence of a fivefold molar excess of BSA, $\alpha$-lactalbumin, $\beta$ lactoglobulin, lactoferrin and cow's- and goat's-milk FBP with a reaction time of $15 \mathrm{~min}$ and $\mathrm{pH}$ of 5.0. (5) A 15 min reaction time and $\mathrm{pH}$ of $5 \cdot 0$ was used to study the uptake of 


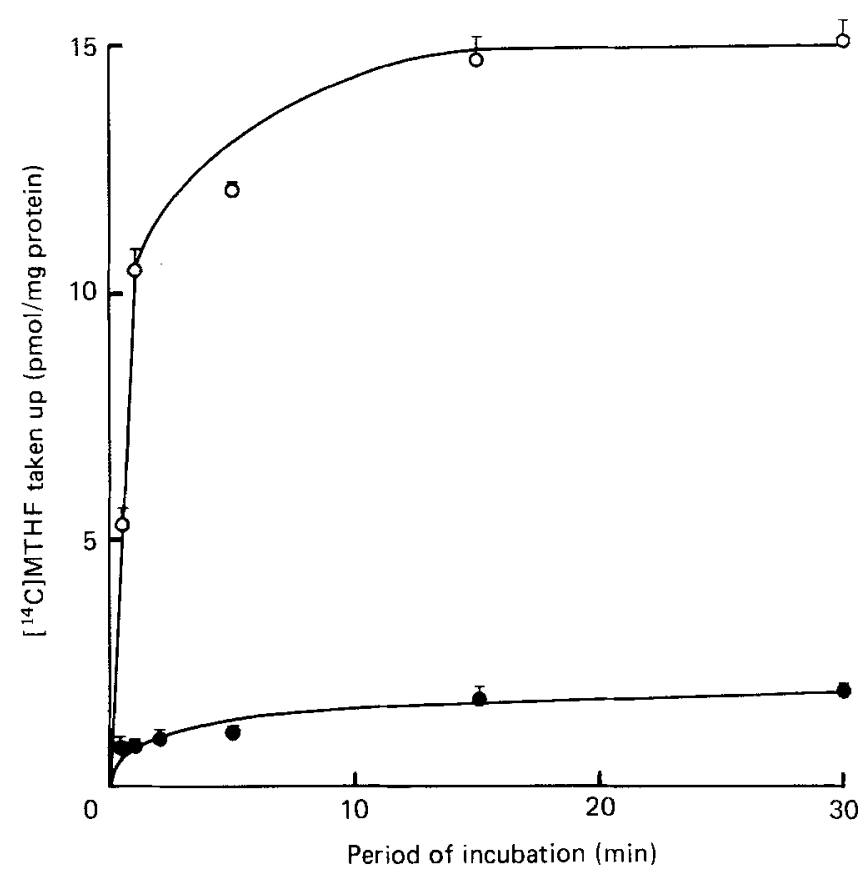

Fig. 2. The time course of uptake of free $5-\left[{ }^{14} \mathrm{C}\right]$ methyltetrahydrofolate (MTHF) and $\left[{ }^{14} \mathrm{C}\right] \mathrm{MTHF}$ complexed to folate-binding protein (FBP) by brush-border-membrane vesicles. Membrane vesicles $\left(50 \mu \mathrm{g}\right.$ protein) were incubated with $\left[{ }^{14} \mathrm{C}\right] \mathrm{MTHF}(0.5 \mu \mathrm{M})$ in the absence $(O)$ and presence $(\mathrm{O})$ of FBP $(0.5 \mu \mathrm{M})$ for $0.5-30 \mathrm{~min}$ at $25^{\circ}, \mathrm{pH} 5 \cdot 0$. Results are the means of three determinations, with their standard errors represented by vertical bars.

${ }^{125}$ I-labelled FBP $(0 \cdot 1-40 \mu \mathrm{g} / \mathrm{ml})$ at steady-state. Uptake of saturated ${ }^{125}$ I-labelled FBPMTHF complex (prepared by incubation of ${ }^{125}$ I-labelled FBP with MTHF in a molar ratio $1: 5$ for $1 \mathrm{~h}$ at $0^{\circ}$ ) was also measured under these conditions. Results were plotted as ${ }^{125} \mathrm{I}-$ labelled FBP taken up $v$. unreacted ${ }^{125}$ I-labelled FBP at steady-state. Values for $V_{\max }$ and $K_{m}$ were calculated from these values using a non-linear curve fitting package (MLP) on a Vax 11/750 computer (Digital Equipment Corporation). Results were fitted to the Michaelis-Menten equation $\left(y=b /(1+d x)\right.$ where $b$ is $-V_{\max }$ and $d$ is $\left.1 / K_{m}\right)$ after converting the $y$ values to a logarithmic form $(\log y+$ constant).

\section{RESULTS}

In preliminary experiments to investigate the influence of FBP on folate uptake by brushborder-membrane vesicles, the molar ratio FBP:MTHF was 1:1. Optimal uptake of $\left[{ }^{14} \mathrm{C}\right] \mathrm{MTHF}$ in the presence of FBP occurred at $\mathrm{pH}$ values between 4.5 and 5.5 (Fig. 1); uptake decreased sharply to low values at $\mathrm{pH} 8$ and $\mathrm{pH} 4$. However, the amount of $\left[{ }^{14} \mathrm{C}\right] \mathrm{MTHF}$ taken up by the vesicles in the presence of FBP at pH 4.5-5.5 was 50-100 times higher than that observed when no FBP was added to the incubation medium. A pH of $5 \cdot 0$ was used for the subsequent experiments.

Fig. 2 shows the time course of uptake of $\left[{ }^{14} \mathrm{C}\right] \mathrm{MTHF}$ with and without added FBP. This shows that both the initial rate (1 min uptake) and final uptake at steady-state of folate were increased markedly. 
Table 1. The effect of various concentrations of folate-binding protein (FBP) on 5methyltetrahydrofolate (MTHF) uptake (pmol MTHF taken up/mg membrane protein per $30 \mathrm{~min}$ ) at steady-state by brush-border-membrane vesicles

(Values are the means of six determinations with their standard errors. Membrane vesicles $(50 \mu \mathrm{g}$ protein) were incubated with $\left[{ }^{14} \mathrm{C}\right] \mathrm{MTHF}(0.5,1$ and $2 \mu \mathrm{M})$ for $30 \mathrm{~min}$ at $\mathrm{pH} 5.0$ with various concentrations of FBP)

\begin{tabular}{|c|c|c|c|c|c|c|}
\hline \multirow{2}{*}{$\begin{array}{l}\text { FBP:MTHF } \\
(\mathrm{mol} / \mathrm{mol})\end{array}$} & \multicolumn{2}{|c|}{$0.5 \dagger$} & \multicolumn{2}{|c|}{$1 \dagger$} & \multicolumn{2}{|c|}{$2 \dagger$} \\
\hline & Mean & SE & Mean & SE & Mean & $\mathrm{SE}$ \\
\hline 0 & 0.36 & 0.22 & $1 \cdot 19$ & 0.2 & 2.04 & $0 \cdot 2$ \\
\hline $0 \cdot 25$ & 12.5 & $3 \cdot 6$ & $11 \cdot 1$ & 3.9 & 71.6 & $16 \cdot 5$ \\
\hline 0.5 & 260 & $4 \cdot 5$ & $25 \cdot 5$ & $10 \cdot 5$ & $80 \cdot 2$ & 8.7 \\
\hline 1.0 & $58 \cdot 6$ & $20 \cdot 5$ & $76 \cdot 8$ & 260 & 276.0 & 87.9 \\
\hline 2.5 & 84.8 & 15.9 & 113.3 & 56.4 & $294 \cdot 0$ & 96.9 \\
\hline 5.0 & $77 \cdot 8$ & $29 \cdot 1$ & $10^{9} \cdot 0$ & $25 \cdot 3$ & 113.0 & 33.9 \\
\hline
\end{tabular}

$\dagger$ Initial $\left[{ }^{14} \mathrm{C}\right] \mathrm{MTHF}$ concentration $(\mu \mathrm{M})$.

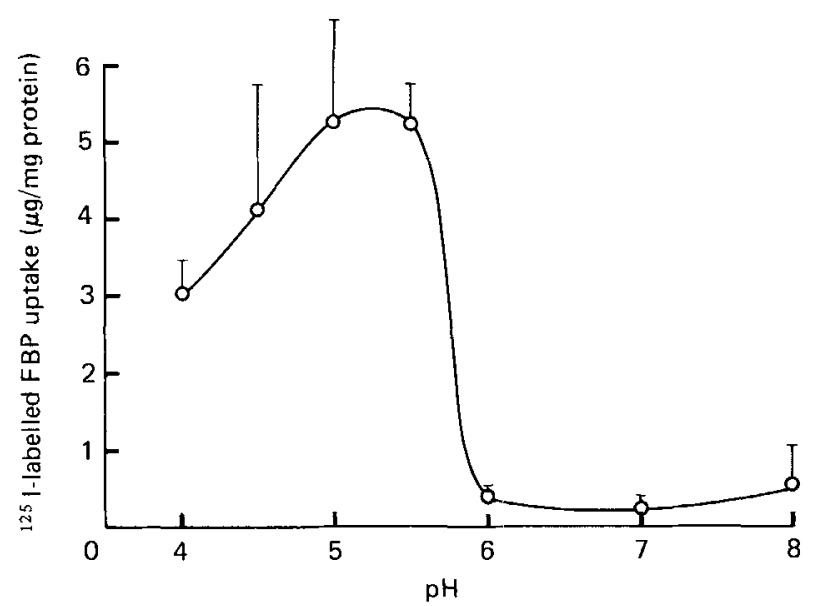

Fig. 3. The effect of $\mathrm{pH}$ on the uptake of ${ }^{125} \mathrm{I}$-labelled folate-binding protein (FBP) by brush-bordermembrane vesicles. Membrane vesicles ( $50 \mu \mathrm{g}$ protein) were incubated with ${ }^{125} \mathrm{I}$-labelled FBP $(20 \mu \mathrm{g} / \mathrm{ml})$ for $15 \mathrm{~min}$ at $25^{\circ}, \mathrm{pH} 4-8$. Results are the means of three experiments, with their standard errors represented by vertical bars.

To study the influence of varying the molar ratio FBP:MTHF on the uptake of $\left[{ }^{14} \mathrm{C}\right] \mathrm{MTHF}$, a reaction time of $30 \mathrm{~min}$ was used by which time the uptake process was at steady-state (Table 1). Significant enhancement in $\left[{ }^{14} \mathrm{C}\right] \mathrm{MTHF}$ uptake was observed at relative molar ratios FBP:MTHF of $0 \cdot 25$ and above. Maximal increases in $\left[{ }^{14} \mathrm{C}\right] \mathrm{MTHF}$ uptake were observed at a molar ratio FBP:MTHF of $1-2 \cdot 5$. At this ratio $\left[{ }^{14} \mathrm{C}\right] \mathrm{MTHF}$ uptake was increased by $95-235$-fold compared with the uptake of $\left[{ }^{14} \mathrm{C}\right] \mathrm{MTHF}$ in the absence of added FBP. The enhancement in $\left[{ }^{14} \mathrm{C}\right] \mathrm{MTHF}$ uptake began to decline as the molar ratio FBP: MTHF increased above 2.5 , uptake at a molar ratio of 5.0 being $38 \%$ of optimal uptake at an initial dose of $2 \mu \mathrm{M}-\left[{ }^{14} \mathrm{C}\right] \mathrm{MTHF}$.

The influence of incubation medium $\mathrm{pH}$ on uptake of ${ }^{125}$ I-labelled FBP by brush-bordermembrane vesicles is shown in Fig. 3. Uptake of ${ }^{125} \mathrm{I}$-labelled FBP reached a maximum at 


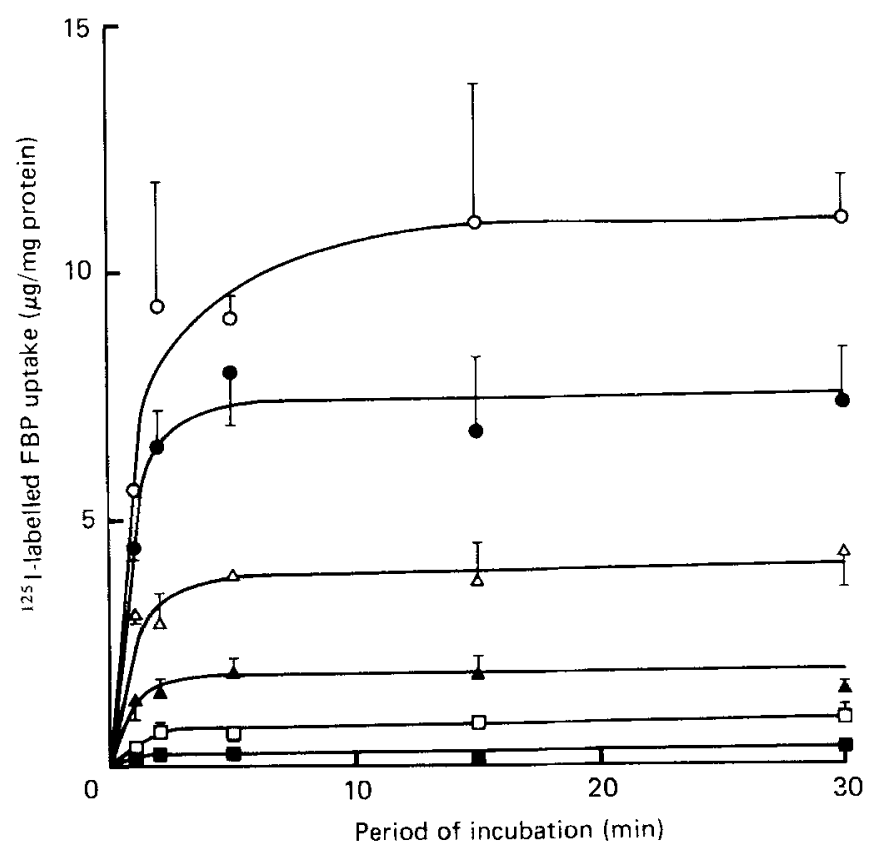

Fig. 4. The time-course of uptake of ${ }^{125}$ I-labelled folate-binding protein (FBP) by brush-bordermembrane vesicles. Membrane vesicles $(50 \mu \mathrm{g}$ protein) were incubated with various concentrations $(\mu \mathrm{g} / \mathrm{ml})$ of ${ }^{125} \mathrm{I}$-labelled FBP $(\boldsymbol{C}), 1 ;(\square), 2 ;(\boldsymbol{A}), 4 ;(\triangle), 10 ;(\bullet), 20 ;(\mathrm{O}), 40$ for $1-30 \mathrm{~min}$ at $25^{\circ}, \mathrm{pH} 5.0$. Results are the means of three determinations, with their standard errors represented by vertical bars. Where no bars are shown the standard errors fall within the experimental points as drawn.

$\mathrm{pH} 5-5.5$ but fell sharply at higher $\mathrm{pH}$ values, and in subsequent experiments the medium was buffered at pH 5.0. The influence of the concentration of FBP on the time course of uptake of ${ }^{125} \mathrm{I}$-labelled FBP is shown in Fig. $4 .{ }^{125} \mathrm{I}$-labelled FBP was taken up rapidly by brush-border-membrane vesicles and a steady-state was established in 5-15 min. Uptake at steady-state increased with increasing dose of ${ }^{125}$ I-labelled FBP and there was evidence of saturation at the higher doses (uptake at a dose of $40 \mu \mathrm{g} / \mathrm{ml}{ }^{125}$ I-labelled FBP was only $47 \%$ greater than that at $20 \mu \mathrm{g} / \mathrm{ml}^{125}$ I-labelled FBP). Fig. 5 shows the effect of increasing the osmotic pressure of the medium on ${ }^{125}$ I-labelled FBP uptake. The uptake of ${ }^{125}$ I-labelled FBP was reduced relatively little by successively increasing concentrations of cellobiose in the incubation medium and by extrapolation of the curve it was estimated that the decrease at infinite osmotic pressure was $27 \%$. The effect of competition of other milk proteins at a fivefold molar excess with ${ }^{125}$ I-labelled FBP for uptake by the vesicles is shown in Table 2. Bovine serum albumin and $\alpha$-lactalbumin had no significant effect on ${ }^{125}$ I-labelled FBP uptake. Bovine $\beta$-lactoglobulin significantly decreased ${ }^{125}$ I-labelled FBP uptake by approximately $20 \%$, and lactoferrin and cow's- and goat's-milk FBP lowered ${ }^{125}$ I-labelled FBP uptake by approximately 50-60\% compared with control values. In another experiment a twentyfold dilution with goat's-milk FBP reduced ${ }^{125}$ I-labelled FBP uptake to $1.4 \mu \mathrm{g} / \mathrm{mg}$ membrane protein per $15 \mathrm{~min}$.

The uptake of ${ }^{125}$ I-labelled FBP under steady-state conditions is shown in Fig. 6. Uptake of uncomplexed ${ }^{125}$ I-labelled FBP increased with increasing ${ }^{125} \mathrm{I}$-labelled FBP concentration and saturation was achieved at ${ }^{125}$ I-labelled FBP concentrations of $20 \mu \mathrm{g} / \mathrm{ml}(0.57 \mu \mathrm{M})$ and above. Analysis of the results using the MLP computer program gave rise to a value of 


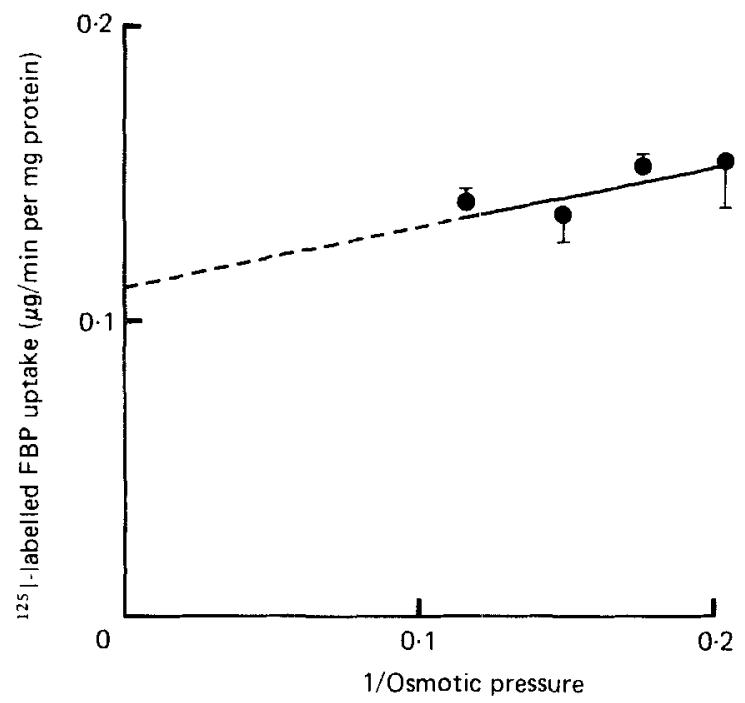

Fig. 5. The effect on ${ }^{125}$ I-labelled folate-binding protein (FBP) uptake by brush-border-membrane vesicles by increasing the osmotic pressure of the medium. Membrane vesicles ( $50 \mu \mathrm{g}$ protein) were incubated with ${ }^{125} \mathrm{I}$-labelled FBP $(1 \mu \mathrm{g} / \mathrm{ml})$ in the presence of $0,10,25$ and $50 \mathrm{~g}$ cellobiose $/ 1$, for $1 \mathrm{~min}$ at $25^{\circ}, \mathrm{pH} 50$. Results are the means of six determinations, with their standard errors represented by vertical bars. The best-fitting straight line was drawn through the points using linear regression analysis. The dashed line shows the extrapolation of this line back to the $y$ axis.

Table 2. The effect of other milk proteins on the uptake of ${ }^{125}$ I-labelled folate-binding protein $(F B P)$ by brush-border-membrane vesicles

(Results are the means of three experiments except where shown; a pooled standard deviation of 1.09 was calculated from the results. Membrane vesicles were incubated with ${ }^{125} \mathrm{I}$-labelled FBP $(20 \mu \mathrm{g} / \mathrm{ml}$, $0.57 \mu \mathrm{M})$ in the presence of a fivefold molar excess $(2.85 \mu \mathrm{M})$ of other milk proteins, for 15 min at $25^{\circ}$, $\mathrm{pH}$ )

\begin{tabular}{lc} 
Competing protein & $\begin{array}{c}{ }^{125} \text { I-labelled FBP uptake } \\
(\mu \mathrm{g} / \mathrm{mg} \text { membrane protein per 15 min })\end{array}$ \\
\hline None & $8.6 \dagger$ \\
Bovine serum albumin & $7 \cdot 5 \mathrm{NS}$ \\
$\alpha$-Lactalbumin & $7.6 \mathrm{NS}$ \\
$\beta$-Lactoglobulin & $6.8^{*}$ \\
Lactoferrin & $4 \cdot 0^{* * *}$ \\
Cow's-milk FBP & $3 \cdot 6^{* * *}$ \\
Goat's-milk FBP & $4 \cdot 4^{* * *}$ \\
\hline
\end{tabular}

NS, not significant.

Mean values were significantly different from that obtained in the absence of a competing protein (Student's $t$ test): ${ }^{*} P<0.05,{ }^{* * *} P<0.001$.

$\dagger$ Six experiments.

$K_{m}$ for uptake of 0.39 (SE 0.07) $\mu \mathrm{M}$ and a value for $V_{\max }$ of 6.73 (SE 0.92$) \mu \mathrm{g} \mathrm{FBP} / \mathrm{mg}$ membrane protein. Uptake values for ${ }^{125}$ I-labelled FBP complexed to MTHF produced higher values of $K_{m}(5.7(\mathrm{SE} 5.5) \mu \mathrm{M})$ and $V_{\max }(37.6(\mathrm{SE} 34.7) \mu \mathrm{g} / \mathrm{mg}$ protein) than were observed for the uncomplexed protein but these were not significantly different ( $P$ lies between $0 \cdot 1$ and $0 \cdot 05$ ). 


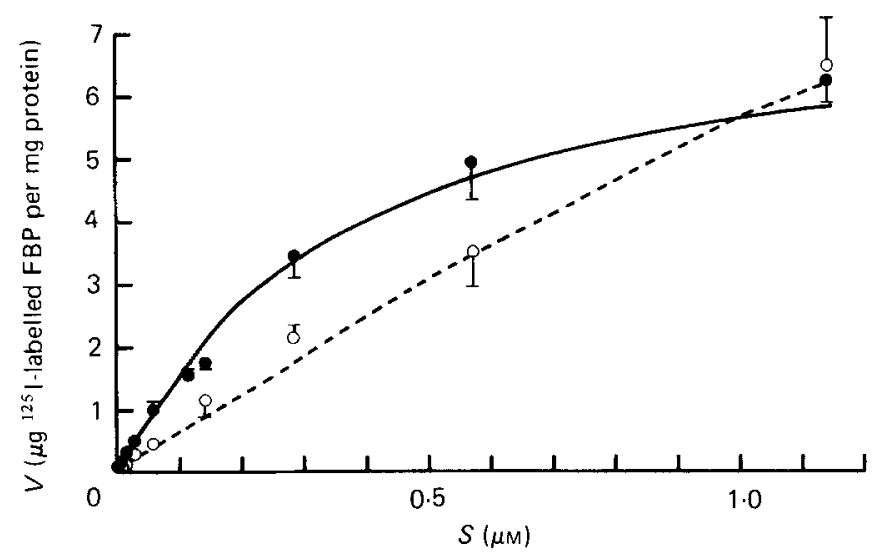

Fig. 6. The uptake under steady-state conditions of ${ }^{125} \mathrm{I}$-labelled folate-binding protein (FBP) by brushborder-membrane vesicles. Membrane vesicles (50 $\mu \mathrm{g}$ protein) were incubated with various concentrations of uncomplexed ${ }^{125}$ I-labelled FBP (O) or ${ }^{125}$ I-labelled FBP complexed with 5-methyltetrahydrofolate $(O)$ for $30 \mathrm{~min}$ at $25^{\circ}, \mathrm{pH} 5.0$. Results were plotted as uptake of FBP $\left(V^{\prime}\right) v$. initial FBP concentration $(S)$, and are the means of six experiments, with their standard errors represented by vertical bars. The curves were drawn as calculated by the MLP computer program.

\section{DISCUSSION}

Free folates are taken up by brush-border-membrane vesicles and enterocytes by a saturable carrier-mediated process located in the brush-border membrane, but the capacity of the system is low and characteristically only one-thousandth of the dose is taken up (Selhub \& Rosenberg, 1981; Blakeborough \& Salter, 1988). The present results provide evidence that uptake of MTHF was strongly promoted by FBP isolated from goat's milk, in a manner analogous to that reported for the effect of sow's milk vitamin $B_{12}$ binding protein on uptake of vitamin $\mathbf{B}_{12}$ by brush-border-membrane vesicles isolated from neonatal pig intestine (Trugo et al. 1985). Indeed, the observed enhancement was an order of magnitude greater than that of the vitamin $\mathrm{B}_{12}$ binder on vitamin $\mathrm{B}_{12}$ uptake.

The $\mathrm{pH}$ at which optimum folate uptake occurred in the presence of FBP (5.0) was similar to that for uptake in the absence of the protein, but there was proportionately much lower uptake at $\mathrm{pH}$ values on the alkaline side of neutrality. The protein was therefore most effective within the $\mathrm{pH}$ range found in the acidic microenvironment which exists at the surface of the brush-border membrane (Blair \& Matty, 1974; Lucas et al. 1975). Kinetic studies showed that the time-course of folate uptake by brush-border-membrane vesicles in the presence of the binding protein was similar to that in its absence, in that equilibrium was reached in $15-30 \mathrm{~min}$, but the initial rate and total uptake were greatly increased. Uptake of folate was found to be highly dependent on the molar proportions of FBP to MTHF with an optimum ratio $1-2 \cdot 5: 1$. The decrease observed at higher molar ratios was presumably due to competition of free binder for sites occupied by binder complexed to MTHF.

Studies of uptake of the ${ }^{125}$ I-labelled FBP by brush-border-membrane vesicles suggest a mechanism by which it might function to facilitate folate transport. Uptake of ${ }^{125}$ I-labelled FBP was $\mathrm{pH}$ dependent, its optimum coinciding with the $\mathrm{pH}$ optimum for MTHF uptake, and it was shown by kinetic and steady-state studies to be saturable. These features are consistent with an uptake process whereby FBP binds to a saturable receptor molecule on the brush-border-membrane surface (Lever, 1980). Results with cellobiose added to the 
medium indicated that uptake of the protein was primarily due to surface binding (Hopfer et al. 1973), with little transport of FBP across the membrane. The strong bond between MTHF and FBP at neutral pH (Salter et al. 1981), characteristic of that prevailing within the gut lumen, would be weakened by binding of the FBP-folate complex to the brush border in the slightly acidic microenvironment at the membrane surface, where MTHF would be released. Uptake by the endogenous transport mechanism $\left(K_{m}\right.$ approximately $10^{-5} \mathrm{M}$ at $\mathrm{pH} 5 \cdot 0$ ) would thus be ensured. Increased transport of MTHF across the brushborder membrane was indicated by the present study. Whilst saturation of FBP binding to the brush-border membrane occurred at approximately $6 \mu \mathrm{g} / \mathrm{mg}$ membrane protein (171 pmol, Fig. 6) the maximum uptake of MTHF observed was $294 \mathrm{pmol} / \mathrm{mg}$ membrane protein (Table 2). The implication of these results is that an increase in MTHF uptake over and above that due to the binding of a MTHF-FBP complex of molar ratio 1:1 is due to transport.

The effect of FBP on uptake of MTHF by the ileal cell membrane shows a superficial resemblance to that of intrinsic factor or of the milk cobalamin-binding protein on cobalamin uptake. Binding of FBP and FBP-MTHF complex to the ileal membrane ( $K_{m} 0.39$ and $5.7 \mu \mathrm{M}$ respectively) was less avid than that of intrinsic factor and intrinsic factor-cobalamin complex to its receptor $\left(K_{d} 1.1\right.$ and $6.7 \mathrm{nM}$ respectively; Seetharam et al. 1983) but, like intrinsic factor, FBP showed a possible tendency to bind more strongly when uncomplexed to vitamin. There was an indication however that capacity for FBP uptake increased when it was complexed to MTHF (Fig. 6). The intrinsic factor-cobalamin complex binds optimally to the ileal receptor at neutral $\mathrm{pH}$, is internalized by endocytosis (Robertson \& Gallagher, 1985) and does not bind to the receptor below pH 5.4 (MacKenzie \& Donaldson, 1972). Sow's-milk cobalamin-binding protein is also optimally effective at neutral pH (Trugo et al. 1985). The FBP-MTHF complex, however, binds optimally to the enterocyte membrane at $\mathrm{pH} 5-5.5$ and does not appear to be internalized as the complex. Again, whereas intrinsic factor binds cobalamin strongly at $\mathrm{pH} 5$, FBP binds MTHF only weakly at this $\mathrm{pH}$ (Ford et al. 1969). These differences imply different roles for the respective binding proteins in uptake of the two vitamins.

Despite the very marked response of folate uptake to the presence of FBP, which suggested a specific effect, two proteins (lactoferrin and $\beta$-lactoglobulin) in addition to goat's- and cow's-milk FBP were able to compete to varying extents with FBP for binding sites on the brush-border membrane. However, $\alpha$-lactalbumin and BSA, both of which are present in milk, were without effect. Inhibition by fivefold additional FBP was less than anticipated. In another experiment a twentyfold dilution with goat's-milk FBP reduced ${ }^{125}$ I-labelled FBP binding to $1.4 \mu \mathrm{g} / \mathrm{mg}$ membrane protein per $15 \mathrm{~min}$. The relatively lower effectiveness of FBP in displacing ${ }^{125}$ I-labelled FBP at higher concentrations is presumably a consequence of concentration-dependent polymerization known to be a property of this protein (Ford et al. 1969). Lactoferrin is known to bind avidly to the brush-border membrane and can coat the entire mucosal surface (Masson et al. 1969). It may therefore reduce the binding of ${ }^{125}$ I-labelled FBP to the membranes. This is unlikely to be an important factor in goat's and cow's milks which contain little lactoferrin (Masson \& Heremans, 1971), but may be of significance in human milk which contains up to $5 \mathrm{mg}$ lactoferrin/ml (Nagasawa et al. 1972). Commercial $\beta$-lactoglobulin preparations are known to contain relatively large amounts of cow's-milk FBP as an impurity (Waxman \& Schreiber, 1975) which, without doubt, contributed to the observed partial inhibition of the binding of ${ }^{125}$ I-labelled FBP to brush-border membranes.

There has been much speculation concerning the role of FBPs in the cellular biochemistry of folates, but little direct evidence for their participation (Kane et al. 1986). It has been pointed out that the high folate affinities of membrane-associated FBP isolated from 
various tissues, including pig and rat kidney, rat liver, hog choroid-plexus, etc. $\left(K_{d} 10^{-9}-10^{-10} \mathrm{M}\right.$; Wagner, 1982) are of the same order of magnitude as those reported for other recognized membrane receptors, making them logical candidates for a physiological transport role. Binding of folic acid to rat intestinal epithelial cells $\left(K_{d} 4 \times 10^{-5} \mathrm{M}\right.$; Leslie \& Rowe, 1972) and neonatal-goat intestinal brush-borders $\left(K_{d} 2 \times 10^{-5} \mathrm{M}\right.$; Eilam et al. 1981; Blakeborough \& Salter, 1988) was weaker, however, by several orders of magnitude. Close structural homology between particulate and soluble forms of FBP, shown by their immunologic cross-reactivity has led to conjecture that soluble FBPs such as milk FBP are produced by specific proteolytic cleavage of an insoluble membrane protein. Such a precursor--product relation has been supported by pulse-chase studies in human KB cells in which the membrane-associated and soluble FBP were labelled endogenously with ${ }^{[35}$ S]methionine (Kane et al. 1984). Evidence for a similar relation for the particulate and soluble binders of human milk, based on the constancy of the value $1: 1$ for folate:FBP and evidence that folylpolyglutamates do not cross biological membranes, has also been put forward (Selhub et al. 1984). A precursor-product relation between the soluble milk FBP and a membrane-associated FBP in the mammary epithelium does not, however, preclude a physiological role in the suckling animal, such as was suggested by Ford (1974) and Herbert et al. (1979). Indeed, the reported enhancement of folate uptake in rat enterocytes by skimmed milk (Colman et al. 1981) indicated a need for further investigation, which has been met by the studies described in the present paper.

We conclude that the evidence presented here shows that a folate transport mechanism mediated by the milk FBP exists at the intestinal brush-border of neonatal goat kids, although the physiological importance of the binding protein for the folate nutrition of the kid remains to be further elucidated. Uptake appears to involve binding of FBP to a receptor in the cell membrane, to which it attaches most readily under the slightly acidic conditions prevailing at the mucosal surface, this environment also being favourable for release of the bound MTHF. At the neutral $\mathrm{pH}$ usually found in the intestinal lumen, MTHF is very strongly bound to FBP ( $K_{d} 50 \mathrm{pM}$; Salter et al. 1981). A consequence of this very high affinity would be to sequester any free folate within the digestive tract and channel it to the absorptive surface. It is possible that such a mechanism would assist conservation of folate synthesized in the developing rumen, which begins to function at a low level between 1 and 3 weeks of age, although weaning does not take place until 6-8 weeks under current practice or 12-16 weeks under natural conditions. Similarly folate excreted into the small intestine in bile could be recovered. Liver reserves average about $230 \mu \mathrm{g}$ folate $(60 \%$ of whole-body folate) in the kid at birth (Ford et al. 1972), and the rate at which these become depleted is not known. However, it may be calculated that during the first week after birth a kid receives in the milk about $500 \mu \mathrm{g}$ folate, accompanied by a two- to threefold surplus of folate-binding capacity, assuming a daily intake of 1 litre milk with an average of $75 \mu \mathrm{g}$ folate/1, potentially sufficient to restore the entire liver folate reserves. The folate content of goat's milk falls rapidly after parturition, reaching less than $10 \mu \mathrm{g} / 1$ after $14 \mathrm{~d}$, whereas the FBP concentration falls relatively slowly and maintains a surplus folatebinding capacity in excess of $100 \mu \mathrm{g} / 1$ for $30 \mathrm{~d}$ or more (Ford et al. 1972). This excess FBP may be important during the period when the kid is relying increasingly on its folate reserves, when milk folate intake is very low, and rumen synthesis is at an early stage. Further investigations will be required to determine whether or not the capacity of the uptake mechanism of the neonatal kid for free folate is sufficient to meet the animal's full requirements. The present work suggests that this capacity could be greatly increased by milk FBP, and that it may be a means of facilitating folate absorption until endogenous mechanisms become fully developed. 
The authors are pleased to acknowledge the assistance of Ms S. G. Neville with the research, $\mathrm{Mr} \mathrm{A}$. Mowlem for his management of the goats and $\mathrm{Dr} \mathrm{D}$. Hewitt and $\mathrm{Mr} \mathrm{S}$. Kirby for their help with the statistical treatment of the results and using the computer program. They are grateful to Professor R. R. Dils for reading the manuscript.

\section{REFERENCES}

Antony, A. C., Kane, M. A. \& Kolhouse, J. F. (1983). Blood 62, 35a.

Bensadoun, A. \& Weinstein, D. (1976). Analytical Biochemistry 70, 241-250.

Blair, J. A. \& Matty, A. J. (1974). Clinics in Gastroenterology 3, 183-197.

Blakeborough, P. \& Salter, D. N. (1985). Abstracts of the XIIIth International Congress of Nutrition, Brighton, p. 149.

Blakeborough, P. \& Salter, D. N. (1988). British Journal of Nutrition 59, 485 495.

Blakeborough, P., Salter, D. N. \& Gurr, M. I. (1983). Biochemical Journal 209, 505-512.

Bolton, A. E. \& Hunter, W. M. (1973). Biochemical Journal 133, 529-539.

Colman, N., Hettiarachchy, N. \& Herbert, V. (1981). Science 211, 1427-1429.

Eilam, Y., Ariel, M., Jablonska, M. \& Grossowicz, N. (1981). American Journal of Physiology 240, G170-G175.

Ford, J. E. (1974). British Journal of Nutrition 31, 243-257.

Ford, J. E., Knaggs, G. S., Salter, D. N. \& Scott, K. J. (1972). British Journal of Nutrition 27, 571-583.

Ford, J. E., Saiter, D. N. \& Scott, K. J. (1969). Journal of Dairy Research 36, 435446.

Herbert, V., Hettiarachchy, N. \& Colman, N. (1979). Blood 54, Suppl. 1, 39A.

Hopfer, U., Nelson, K., Perrotto, J. \& Isselbacher, K. I. (1973). Journal of Biological Chemistry 248, $25-32$.

Kane, M. A., Antony, A. C. \& Kolhouse, J. F. (1984). Clinical Research 32, 310 a.

Kane, M. A., Kolhouse, J. F. \& Waxman, S. (1986). In Proceedings of the XIIIth International Congress of Nutrition, pp. 447-450 [T. G. Taylor and N. K. Jenkins, editors]. London: John Libby.

Leslie, G. J. \& Rowe, P. B. (1972). Biochemistry 11, 1696-1703.

Lever, J. E. (1980). CRC Critical Reviews of Biochemistry 7, 187-246.

Lucas, M. L., Schneider, W., Haberich, F. J. \& Blair, J. A. (1975). Proceedings of the Royal Society of London series B 192, 39-48.

MacKenzie, I. L. \& Donaldson, R. M. (1972). Journal of Clinical Investigation 51, 2465-2471.

Masson, P. L. \& Heremans, J. F. (1971). Comparative Biochemistry and Physiology 39 B, 119-129.

Masson, P. L., Heremans, J. F., Schonne, E. \& Crabbe, P. A. (1969). Protides of the Biological Fluids 16, 633-638.

Nagasawa, T., Kiyosawa, I. \& Kuwahara, K. (1972). Journal of Dairy Science 55, 1651-1659.

Robertson, J. A. \& Gallagher, N. D. (1985). Gastroenterology 88, 908-912.

Salter, D. N., Scott, K. J., Slade, H. \& Andrews, P. (1981). Biochemical Journal 193, 469-476.

Seetharam, B., Bakke, J. E. \& Alpers, D. H. (1983). Biochemical and Biophysical Research Communications 115 , 238-244.

Selhub, J., Arnold, R., Smith, A. M. \& Picciano, M. F. (1984). Nutrition Research 4, 181-187.

Selhub, J, \& Rosenberg, I. H. (1981). Journal of Biological Chemistry 256, 4489-4493.

Svendsen, I., Hansen, S. I., Holm, J. \& Lyngbye, J. (1982). Carlsberg Research Communications 47, 371 -376.

Trugo, N. M. F., Ford, J. E. \& Salter, D. N. (1985). British Journal of Nutrition 54, 269-283.

Trugo, N. M.F. \& Salter, D. N. (1986). In Proceedings of the XIIIth International Congress of Nutrition, pp. 453-456 [T. G. Taylor and N. K. Jenkins, editors]. London: John Libby.

Wagner, C. (1982). Annual Review of Nutrition 2, 229-248.

Waxman, S. \& Schreiber, C. (1975). Federation of European Biochemical Societies Letters 55, 128-130. 